Bangladesh J. Zool. 42(2): 161-168, 2014

\title{
PREVALENCE OF DENGUE FEVERS AMONG THE PATIENTS OF DIFFERENT ECONOMIC STATUS ATTENDED AT LOCAL HOSPITAL IN DHAKA
}

\author{
Rimi Farhana, Khan Fatema Awatef, Hamida Khanum \\ and Tangin Akter \\ Department of Zoology, University of Dhaka, Dhaka-1000, Bangladesh
}

\begin{abstract}
Blood samples were collected from patients experiencing a febrile illness clinically consistent with dengue infection in IBN SINA hospital, Dhaka. Dengue specific antibodies were detected by using SD Bioline IgM and IgG Rapid Test. Out of suspected cases, 300 patients were confirmed as serologically positive for dengue fever (DF) and 60 patients for dengue hemorrhagic fever (DHF). Larger proportions of serologically positive cases were observed among the females 54\% in DF and $60 \%$ in DHF than the males $46 \%$ in DF and $40 \%$ DHF. The highest DF and DHF infected age groups were in between 21 and 30 years, and the common symptoms were fever $(100 \%)$ and skin rash $(100 \%)$. The duration of the fever was 5 days which was $26 \%$ in DF and $35 \%$ DHF.
\end{abstract}

Key words: Dengue fever, dengue hemorrhagic fever and socio-economic status

\section{INTRODUCTION}

Dengue fever is an acute viral infection characterized by fever. It is caused by dengue virus carried in a mosquito vector Aedes aegypti. The four dengue viruses, viz. DEN1 to DEN4, are immunologically related, but do not provide cross protective immunity against each other (CDC 2007). It has been estimated that 50 to 100 million cases of the disease per year occurred worldwide and about 250,000 individuals per year manifest the severe forms, which have the mortality rate of about 10 percent (Gubler 1997).

The secondary forms of this disorder are called Dengue Hemorrhagic Fever and Dengue Shock Syndrome. These are usually caused by a secondary infection with a different type of dengue virus, but may also be caused by the same virus that causes dengue fever. Dengue hemorrhagic fever is more severe form of the viral illness (Khan and Ahmed 1986). Manifestations of the disease include headache, fever, rash, and evidence of hemorrhage in the body (Rahman et al. 2000, Blacksell 2006).

The first reported epidemics of dengue fever occurred in 1779-1780 in Asia, Africa, and North America; in South East Asia a global pandemic of dengue after World war-II; the epidemic remained localized in this area till 1970 involving Thailand, Myanmar and other neighboring countries; in 1980 and 1990, the epidemic DHF spread west India, Pakistan, Srilanka, Maldives (Malavige et al. 2004). 
The global prevalence of dengue has grown dramatically in recent years (Dengue Bulletin 2010). Not only is the number of cases increasing as the disease is spreading to new areas, but explosive outbreak of the disease is occurring as its epidemiological pattern is gradually changing. Primarily the virus is found in sub-tropical climates and is thought to be present in 100 countries (Gubler 1997). It has been investigated that DFF and DHF are common and there may increase in Southeast Asia, Thailand, Vietnam, Singapore and Malaysia (Harving and Ronsholt 2007).

In Bangladesh, the first outbreak of dengue fever was documented in 1964 in Dhaka; the first epidemic of DHF occurred in mid 2000, when 5,551 dengue infections were reported from Dhaka, Chittagong and Khulna cities, occurring mainly among adults; the case fatality rate was reported $1.7 \%$ with 93 deaths reported (Rahman et al. 2002). Regarding the morbidity, mortality and economic costs, dengue is the most important mosquito-borne disease in the world, with an estimated 50-100 million infections annually. Dengue fever was unknown in Bangladesh until an outbreak occurred in 1964. The real alarming information came from the spot checked by WHO consultant in different areas of Dhaka and Chittagong city when Breteau Index (BI) in Dhaka city was 30.8, a figure well above the risk levels (Mahmood and Mahmood 2011).

In 1960 summer, an outbreak of DF ( $>5,000$ hospitalized cases reported) and DHF occurred in Dhaka and other major cities of Bangladesh. This first outbreak highlights the geographic expansion of DHF in Bangladesh, where classic DF caused by multiple serotypes had been previously reported. The DHF outbreak started in late June 2000 peaked in September (during the rainy season), and subsided in the dry winter season in December 2000. While dengue affected all age groups, adults predominated in this hospital monitored study. The precise magnitude of this countrywide outbreak is unknown; 5,575 hospitalized dengue cases were reported to the Ministry of Health in Bangladesh, with a case-fatality rate of $1.61 \%$ through mid-November 2000. Most patients had DF, 25\% with bleeding manifestations (Rahman et al. 2002).

The objective of the study was to find out positive case of dengue patients at a hospital in Dhaka City, to determine the prevalence of DF and DHF patients among different age groups of both sexes in addition to socio-economic conditions of the patients.

\section{MATERIAL AND METHODS}

The study was conducted from February to December, 2009 at the IBN SINA Hospital and Diagnostic Center, Dhaka. Blood samples were collected from the 360 patients of the centre during the study period. All 360 patients of both male 
and female were suspected to be infected with dengue fever and dengue hemorrhagic fever. Some selected patients were interviewed and information were collected regarding the diseases through the filling of a questionnaires. The information of the disease recorded were the patients age, sex, family members, family income, occupation, habit (sleeping places, using bed nets, using insecticide spray), habitat (garden, tub or trees around home), duration of fever, treatments taken, drugs taken, and various kinds of clinical symptoms including high fever, skin rash, eye lesion, gum bleeding, hematuria (bleeding through stool, urine), mucosal bleeding and so on.

Test method: The method of serum separation and preservation, detection and differentiation of IgG and IgM antibodies to dengue virus in blood, and the detection of all four dengue serotypes was followed according to Ranch and Levett (1999) and Grroen (2000).

Test procedure: All kit component and specimen were allowed at room temperature before testing and then removed the test device from foil pouch. Then added $10 \mu \mathrm{l}$ of blood specimen drawn to black line into the square sample well marked "S" and put 3-4 drops of assay diluents into the assay diluents well round shaped. Then the test result was interpreted after 15- 20 min.

Interpretation of the test: When the control line "C" and IgM line " $\mathrm{M}$ " were visible on the test device, the result was positive for IgM antibodies to dengue virus. This was indicative of a primary dengue virus infection. The control line "C" and IgM "M", IgG "G" were visible on the test device was positive for both IgM and IgG antibodies. This was indicative of secondary dengue infection. (Ranch and Levett 1999, Groen 2000).

Data processing: The recorded data including the number of infected patients and previous information were tabulated and calculated. The data was analysed manually by using SPSS statistical software.

\section{RESULTS AND DISCUSSION}

All 300 dengue patients and 60 dengue hemorrhagic infected patients were confirmed by the serological test. Among the clinical features, a common symptom was fever for both DF and DHF. The same result was observed by Gupta et al. (1998), Mahbubur et al. (2002) and Saba et al. (2008).

All DHF patients had skin rash and eye lesions, but in case of DF $100 \%$ patient had skin rash, and $81 \%$ had eye lesions; bleeding through mouth $65 \%$, bleeding through stool $87 \%$, bleeding through urine 53\%, mucosal bleeding $50 \%$ were seen in DHF patients (Table 1). But the results are inconsistence with the study of Shahidul et al. (2009); out of 54 patients, most of them suffered with high fever (75.9\%), followed by abdominal pain (59.3\%), and vomiting (57.4\%). 
Among the infected $300 \mathrm{DF}$ patients and $60 \mathrm{DHF}$ patients, the number of males were $137(46 \%)$, and $24(40 \%)$, respectively and the females were $163(54 \%)$, $36(60 \%)$, respectively (Table 2). The females were more infected with DF and DHF than the males. Most of the times, the females are unaware and to some extent careless about their personal health, it is one the causes of the prevalence of dengue fever more among in the females. Similar results were reported by Thomas et al. (2010).

Table 1. Clinical symptoms and duration of DHF and DF patients surveyed at the IBN SINA Hospital and Diagnostic Centre from February to December 2009.

\begin{tabular}{llcc}
\hline & Skin rash & $\begin{array}{c}\text { Present in infected } \\
\text { patients }(\%), \text { DHF }\end{array}$ & $\begin{array}{c}\text { Present in infected } \\
\text { patients (\%), DF }\end{array}$ \\
\hline Clinical & Symptoms & $60(100)$ & $300(100)$ \\
& Eye lesion & $60(100)$ & $243(81)$ \\
& Bleeding through mouth & $39(65)$ & $49(16)$ \\
& Bleeding through stool & $52(87)$ & $35(12)$ \\
& Bleeding through urine & $32(53)$ & $17(6)$ \\
& Mucosal bleeding & $30(50)$ & 0 \\
& 2 & - & $7(2)$ \\
& 3 & $1(2)$ & $41(14)$ \\
& 4 & $9(15)$ & $67(22)$ \\
& 5 & $21(35)$ & $79(26)$ \\
& 6 & $14(23)$ & $59(20)$ \\
& $7+$ & $15(25)$ & $47(16)$ \\
\hline
\end{tabular}

Table 2. Distribution by age group of the DHF and DF patients surveyed at the IBN SINA Hospital and Diagnostic Centre from February to December 2009.

\begin{tabular}{lcccccc}
\hline $\begin{array}{l}\text { Age } \\
\text { group }\end{array}$ & $\begin{array}{c}\text { No. of infected } \\
\text { patient (\%) DHF }\end{array}$ & $\begin{array}{c}\text { Infected } \\
\text { male (\%) }\end{array}$ & $\begin{array}{c}\text { Infected } \\
\text { female (\%) }\end{array}$ & $\begin{array}{c}\text { No. of infected } \\
\text { patient (\%) DF }\end{array}$ & $\begin{array}{c}\text { Infected } \\
\text { male (\%) }\end{array}$ & $\begin{array}{c}\text { Infected } \\
\text { female (\%) }\end{array}$ \\
\hline $0-10$ & $7(12)$ & 3 & 4 & $45(15)$ & 24 & 21 \\
$11-20$ & $14(23)$ & 5 & 9 & $68(23)$ & 31 & 37 \\
$21-30$ & $20(33)$ & 7 & 13 & $80(27)$ & 35 & 45 \\
$31-40$ & $9(15)$ & 4 & 5 & $48(16)$ & 21 & 27 \\
$41-50$ & $6(10)$ & 3 & 3 & $41(14)$ & 17 & 24 \\
$51-60$ & $3(5)$ & 1 & 2 & $11(3)$ & 6 & 5 \\
$61-70$ & $1(2)$ & 1 & 0 & $7(2)$ & 3 & 4 \\
Total & $60(100)$ & $24(40)$ & $36(60)$ & $300(100)$ & $137(46)$ & $163(54)$ \\
\hline
\end{tabular}

Among the seven categories of age group of the infected DF and DHF patients, the highest numbers of the infected patients of these diseases were $80(27 \%)$, and $20(33 \%)$ respectively both belonging to the age group of $21-30$ years and the minimum infected patients both diseases belonged to 60-70 years of age group (Table 2).

The study also figured out the habit and habitat of the patients. Regarding the patient's habitat, it was observed that 281(94\%) DF patients and 44(73\%) 
DHF patients lived in building; 193(64\%) DF patients and 77\% DHF patients used bed net; 250(83\%) DF patients and 45(75\%) used spray/ insecticides (Table 3).

Table 3. Distribution by house type and habits of the infected patients surveyed at the IBN SINA Hospital and Diagnostic Centre from February to December 2009.

\begin{tabular}{|c|c|c|c|c|c|c|c|c|c|}
\hline & \multicolumn{5}{|c|}{ Types of house } & \multicolumn{2}{|c|}{$\begin{array}{c}\text { Sleeping } \\
\text { Habit }\end{array}$} & \multicolumn{2}{|c|}{ insecticides } \\
\hline & $\begin{array}{l}\text { Thac- } \\
\text { hed }\end{array}$ & $\begin{array}{c}\text { Mud } \\
+ \text { straw }\end{array}$ & Building & $\begin{array}{c}\text { Mud } \\
+ \\
\text { Tin } \\
\text { shed }\end{array}$ & Others & $\begin{array}{l}\text { Use } \\
\text { bed } \\
\text { net }\end{array}$ & $\begin{array}{c}\text { Don't } \\
\text { use } \\
\text { bed net }\end{array}$ & $\begin{array}{c}\text { Use } \\
\text { Spray/ } \\
\text { insecti- } \\
\text { cides }\end{array}$ & $\begin{array}{c}\text { Don't use } \\
\text { spray/ } \\
\text { insecti- } \\
\text { cides }\end{array}$ \\
\hline $\begin{array}{l}\text { DHF } \\
\text { patients (\%) }\end{array}$ & - & - & $44(73)$ & - & $16(27)$ & 46(77) & $14(23)$ & $45(75)$ & $15(25)$ \\
\hline $\begin{array}{l}\text { DF } \\
\text { patients (\%) }\end{array}$ & - & - & $281(94)$ & - & $19(6)$ & $193(64)$ & $107(36)$ & $250(83)$ & $50(17)$ \\
\hline
\end{tabular}

Occupation is directly related to the prevalence of dengue infection, but when the working environment is favorable for the DF and DHF it becomes most important variable which is responsible for higher prevalence. The highest number of patients was student in both DF (24\%) and DHF (35\%), and the lowest number was day laborer DF (6\%) and DHF (7\%). In other cases both DF and DHF patients were businessman (22\% and $18 \%$ respectively) and housewife (18\% and $22 \%$ respectively) (Table 4$)$.

Educational status is not directly related to the prevalence of dengue infection, but when related to the awareness of personal hygiene it considered as an important variable for the study. The maximum prevalence of dengue fever was in graduate level group (23\%) and the lowest was among illiterates $(6 \%)$. The same result was also found in case of dengue hemorrhagic fever patients in which case the disease was highest in the graduate level group (26\%) and lowest among in illiterates (7\%) (Table 4).

Table 4. Distribution by their educational status and occupation of the infected patients surveyed at the IBN SINA Hospital and Diagnostic Centre from February to December 2009.

\begin{tabular}{lcclcc}
\hline $\begin{array}{l}\text { Level of education } \\
\text { of the patients }\end{array}$ & $\begin{array}{c}\text { No. of DF } \\
\text { patients (\%) }\end{array}$ & $\begin{array}{c}\text { No. of DHF } \\
\text { patient (\%) }\end{array}$ & $\begin{array}{c}\text { Occupation of } \\
\text { the patient }\end{array}$ & $\begin{array}{c}\text { No. of DF } \\
\text { patient (\%) }\end{array}$ & $\begin{array}{c}\text { No. of DHF } \\
\text { patient (\%) }\end{array}$ \\
\hline Unable to go school & $45(15)$ & $7(12)$ & Service & $66(22)$ & $11(18)$ \\
Illiterate & $17(6)$ & $4(7)$ & Business & $57(19)$ & $7(11)$ \\
Primary & $55(18)$ & $10(17)$ & Day Labor & $19(6)$ & $4(7)$ \\
Secondary & $63(21)$ & $11(18)$ & House Wife & $55(18)$ & $13(22)$ \\
Graduate & $69(23)$ & $16(26)$ & Student & $72(24)$ & $21(35)$ \\
Masters & $51(17)$ & $12(20)$ & Others & $31(11)$ & $4(7)$ \\
Total & $300(100)$ & $60(100)$ & Total & $300(100)$ & $60(100)$ \\
\hline
\end{tabular}


From the distribution of patients by their monthly income it was found that $11 \%$ of DF and $15 \%$ of DHF patients had monthly income Taka 5000 which was the lowest. The highest number of patients, $70 \%$ of DF and $62 \%$ of DHF had monthly income more than Taka 10,000 (Fig. 1). Among the DF and DHF infected patients, $64 \%$ and $68 \%$ respectively had tubs, $9 \%$ and $7 \%$ respectively had garden, 9\%, 7\% had both tubs and garden in their houses ( Fig. 2).

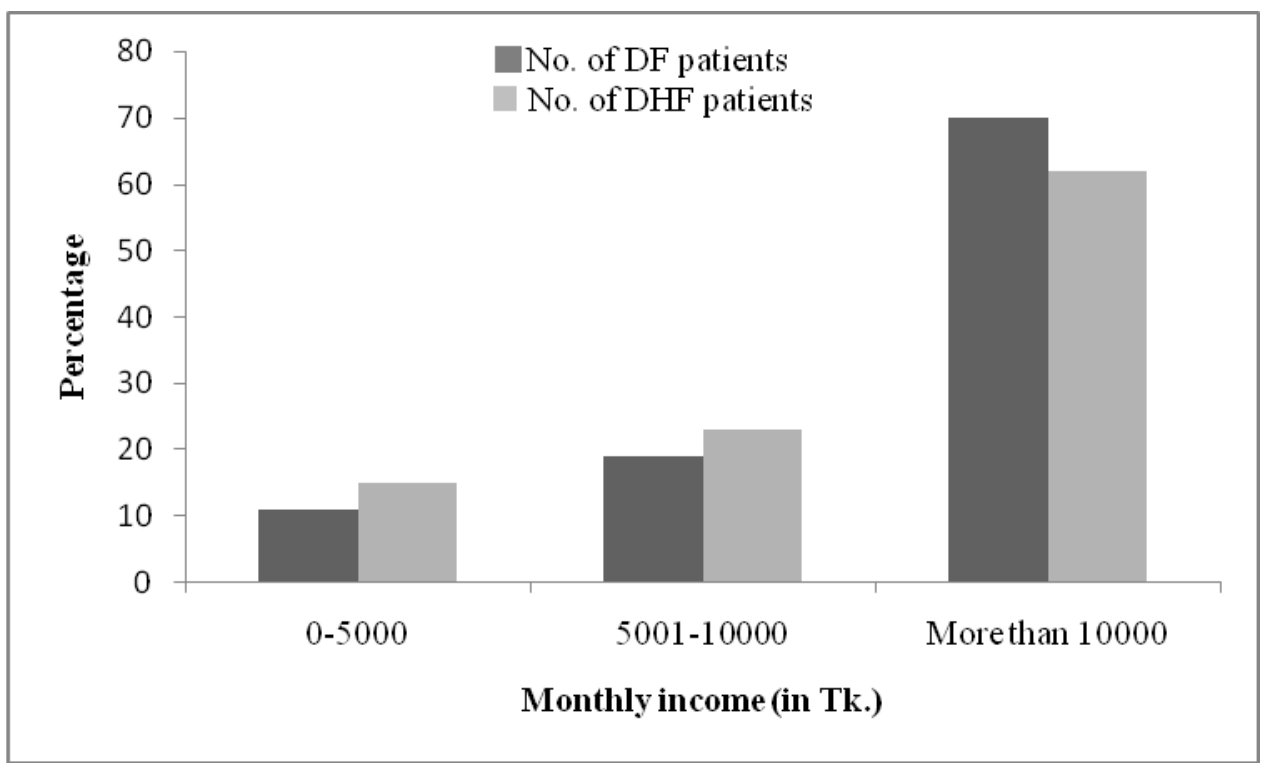

Fig. 1. Distribution of infected patients by their monthly income.

The DF and DHF is now endemic in more than 100 countries and threatens the health of more than 2500 million i.e. $40 \%$ of the world's population. Dengue fever (DF) and dengue hemorrhagic fever (DHF) are caused by four antigenically distinct but related virus serotypes (DEN-1, DEN-2, DEN-3 and DEN-4). However, cross-immunity to the other serotypes after recovery is only partial and temporary. Subsequent infections by other serotypes increase the risk of developing severe dengue. DHF first emerged as a public health problem in 1954, when the first epidemic occurred in Manila. DHF is endemic and frequently intensifies into epidemics in Southeast Asia, resulting in frequent hospitalizations and deaths (Rahman et al. 2002, Mia et al. 2010, Malavige et al. 2004, Peeling and Mabey 2010). 


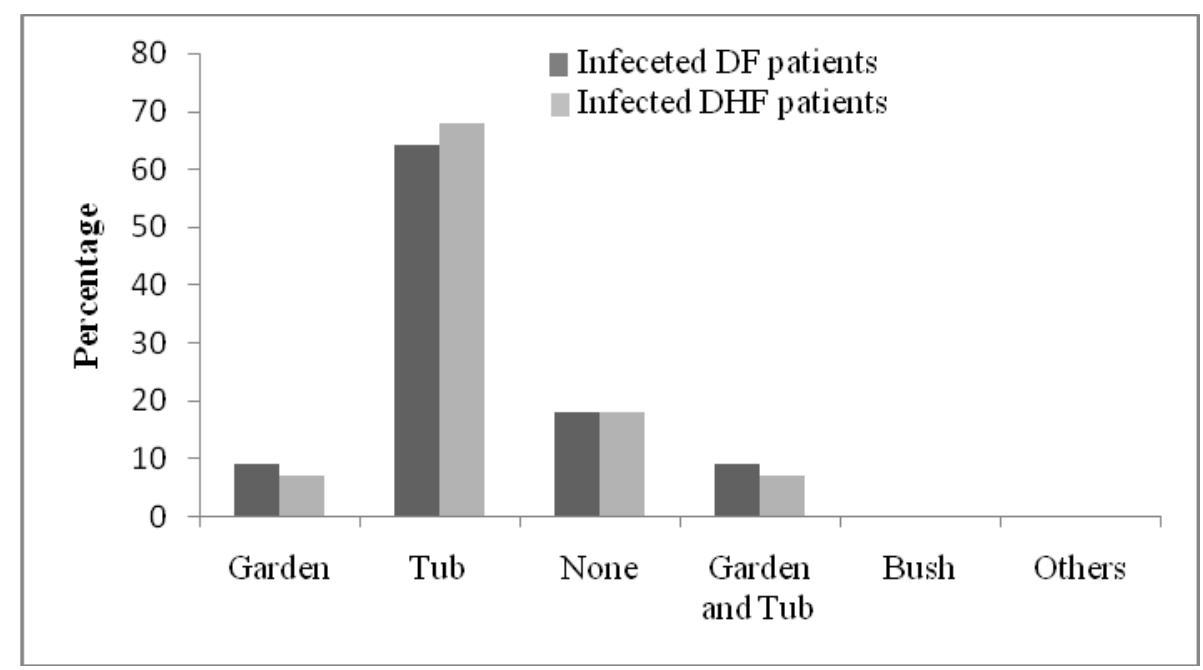

Fig. 2. Types of places in which trees are grown around the houses of infected patients.

From these observations it can be said that DF and DHF is an epidemic diseases prevail in Dhaka city under certain condition, such as awareness of personal hygiene, overcrowding etc. DF was documented in Bangladesh from the mid-1960s to the mid-1990s, but an outbreak of DHF has not been previously reported. Large-scale yearly outbreaks during the rainy season have been occurring in Bangladesh since the year 2000 (Rahman et al. 2002, Mia et al. 2010). During late June 2000, a 28-year-old patient was admitted to a hospital in Dhaka, Bangladesh, with hemorrhagic fever, pleural effusion, and thrombocytopenia.

\section{LITERATURE CITED}

BLACKSELL, S. D. 2006. A systematic review and meta-analysis of the diagnostic accuracy of rapid immunochromatographic assays for the detection of dengue virus IgM antibodies during acute infection. Trans. R. Soc. Trop. Med. Hyg. 100(8):775-784.

CDC 2007. CENTER FOR DISEASE CONTROL, CDC Health Center. Georgia, USA.

DENGUE BULLETIN. 2010. World Health Organization. The South-East Asia and Western Pacific Region. 34: 127.

GROEN, J. 2000. Evaluation of six immunoassays for detection of dengue virus Specific Immunoglobin M and G Antibodies. Clinic. Diagn. Lab. Immunol. 7(6): 867-871.

GUBLER, D.J. 1997. Dengue fever and dengue hemorrhagic fever: its history and resurgence as a global public health problem. New York: CAB International. 7: 1-22.

GUPTA, P., KUMAR, P. and AGGARWAL, O.P. 1998. Knowledge, attitude, and practices related to dengue in rural and slum areas of Delhi after the dengue epidemic of 1996. J. Commun. Dis. 30(2): 107-112.

HARVING, M.L. and RONSHOLT, F.F. 2007. The economic impact of dengue hemorrhagic fever on family level in Southern Vietnam. Dan. Med. Bull. 54(2): 170-172. 
KHAN, A.M. and AHMED, T. U. 1986. Dengue status in Bangladesh. Dengue. Dengue News Letter. 2: 29-31.

MAHBUBUR, R., KHALILUR, R., SIDDIQUE, A.K., SHEREEN, S., KAMAL, A.H.M., ALI, K.S., ANANDA, N. and ROBERT, F.B. 2002. First outbreak of dengue hemorrhagic fever, Bangladesh. Emerg. Infect. Dis. 8(7):738-740.

MAHMOOD, B. and MAHMOOD, S. 2011. Emergence of dengue in Bangladesh a major international public health concern in recent years. J. Environ. Res. Manage. 2(3): 35-41.

MALAVIGE, G.N., FERNANDO, S., FERNANDO D.J. and SENEVIRATNE, S.L. 2004. Dengue viral infections. Postgrad. Med. J. 80(948): 588-601.

MIA, M. W., NURULlAH, A. M., HOSSAIN, A. and HAQUE, M.M. 2010. Clinical and Sonographic Evaluation of Dengue Fever in Bangladesh: A Study of 100 Cases. Dinajpur. Med. Col. J. 3(1): 29-34.

PEELING, R. W. and MABEY, D. 2010. Point-of-care tests for diagnosing infections in the Developing world. Clinic. Microbiol. Infect. 16(8): 1062-1069.

RANCH, S.L. and LEVETT, P. N. 1999. Evaluation of four method for detection of immunoglobulin M antibodies to dengue virus. Clinic. Diagn. Lab. Immunol. 6(4): 555-557.

RAHMAN, M., SIDDIQUE, A.K. and RAHMAN, K. 2000. Emergence of dengue hemorrhagic fever in Bangladesh: Diagnosis, management and prospects for control. The Orion. 7.

RAHMAN, M., RAHMAN, K., SIDDIQUE, A. K., SHOMA, S., KAMAL, A.H.M., ALI, K.S., NISALUK, A. and BREIMAN, R. F. 2002. First outbreak of Dengue Hemorrhagic Fever, Bangladesh. Emerg. Infect. Dis. 8: 738-740.

SABA, A., FEHMINA, A., YOUSUF, Y., ARSHALOOS, R., KASHIF, A. and SAMIN, A. 2008. Dengue fever outbreak in Karachi 2006- A study profile and outcome of children under 15 years of age. J. Pak. Med. Assoc. 58(1): 4-8.

SHAHIDUL, A., ANWAR, S., ZAKARIA, S., AFTAB, U. A., NAJMUL, K., PAUL, H. and SANJANA, Z. 2009. Clinical profile of dengue fever in children. Bangladesh J. Child. Health. 33(2): 55

Thomas, L., BROUSTE, Y., NAJIOUllah, F., HOCHEDEZ, P., HATCHUEL, Y., MORAVIE, V., KAIDOMAR, S., KING, J.P., BESNIER, F., ABEL,S., CARMES, S., SCHMITT, S., BRIHIER, P., CARDOSO, T., ROSINE, J., QUENEL, P., CESAIRE, R. and CABIE, A. 2010. Prospective and descriptive study of emergency department, in Martinique. Med. Mal. Infect. 40(8): 480-489. 